\title{
Legislative Proposal to Increase Sentencing Powers for Cruelty to Nonhuman Animals: Taken with a Pinch of Salt
}

\author{
Oliver A. Wookey \\ English and Spanish Law Degree from the University of \\ Kent, Master in Animal Law and Society at the UAB
}

\author{
Reception: January 2018
}

Acceptance: January 2018

\begin{abstract}
Environment Secretary for the British Government Michael Gove has announced his plan to increase the current maximum sentence that can be awarded to animal abuse offenders from six months to five years. In this critical analysis of the proposal, I will firstly outline the legislative proposal in terms of its aims, and then follow by providing statistics and referring to the most abhorrent cases of cruelty to demonstrate unequivocally the need for the proposal to be implemented. Following this, I will set out the positions of two major relevant stakeholders in response to the proposal: the League Against Cruel Sports, and the RSPCA. I will then proceed to commend the proposal as an important step forward for nonhuman animal welfare, especially given the increasing acknowledgement of the link between violence toward humans and toward nonhuman animals. I will then turn, however, to the two issues that I identify with the proposal and the context within which it has been introduced; firstly, that it highlights our pretension for protecting the welfare of companion animals while simultaneously contributing to the suffering of other animals that are also sentient beings; secondly, that recent Conservative party policies concerning nonhuman animals have been inimical to their welfare and, for this reason, the proposal must be taken with a pinch of salt.
\end{abstract}

Keywords: Animal welfare, animal sentience, companion animals, maximum sentence, the League Against Cruel Sports, anti-speciesism, the RSPCA, critical analysis, Michael Gove

Resumen. Propuesta legislativa para aumentar los poderes de condena por crueldad hacia los animales no humanos. Analizado con reservas.

El ministro del Medio Ambiente del gobierno Británico Michael Gove, ha hecho pública su propuesta de aumentar la pena máxima actual, para culpables de abuso animal, de seis meses a cinco años. En este análisis se critica la propuesta, empezaré por detallar la propuesta legislativa con respecto a sus objetivos y después, a través de unas estadísticas, subrayaré los casos de crueldad más aborrecibles que demuestran inequívocamente la necesidad de implementar la propuesta. A continuación, presentaré las posturas de dos de los responsables 
principales y más relevantes con respecto a la propuesta: la "League Against Cruel Sports", y el "RSPCA". A continuación, presentaré las ventajas de la mencionada propuesta, que significa un importante paso al frente para el bienestar de animales no-humanos, especialmente debido al reconocimiento creciente del vínculo entre violencia hacia humanos y hacia animales no-humanos. Sin embargo, me referiré a continuación a dos aspectos dignos de destacar en la propia propuesta y en el contexto en que ha sido presentada la propuesta; en primer término, que subraya nuestra pretensión de proteger el bienestar de los animales de compañía y proteger a otros animales igualmente sintientes; en segundo término, me referiré a que políticas recientes del Partido Conservador, respecto a los animales no-humanos han sido perjudiciales para su bienestar y, por ese motivo, se debe tomar la mencionada propuesta con reservas.

Palabras clave: Bienestar animal, sensibilidad animal, animales de compañía, antiespecismo, pena máxima, el League Against Cruel Sports, el RSPCA, análisis critica, Michael Gove

Environment Secretary for the British Government Michael Gove has announced his plan to increase the current maximum sentence that can be awarded to animal abuse offenders from six months to five years. The proposal has come about following "a series of cases in which courts said they would have liked to impose tougher sentences if they had the option". It is hoped that "these plans will give courts the tools they have requested to deal with the most abhorrent acts" of animal cruelty.

Current legislation - "set more than 100 years ago by the Protection of Animals Act” - enables judges to punish offenders with a maximum sentence of six months imprisonment, an unlimited fine, and a prohibition from owning an animal in the future. However, statistics reveal that even these minor sentencing powers - among the lowest in Europe - are rarely exercised. According to the Department for Environment, Food and Rural Affairs, "the new legislation will also enable courts to deal more effectively with ruthless gangs involved in organised dog fights".

The proposal seeks to bring English sentencing powers "into line with Australia, Canada, the Republic of Ireland and Northern Ireland", as part of a plan to "deliver worldleading standards of animal welfare in the years ahead". According to the BBC, the "government [is] expected to publish draft legilation for consultation at the end of the year".

The abhorrence of cruelty inflicted on companion animals has, indeed, demonstrated the clear need for increased sentencing powers; currently the judiciary is incapable of bringing justice to the vilest that live among us, with recent cases and national statistics providing unequivocal support for this sentiment. However, this proposal for reform must be met with skepticism for two main reasons, both of which I will identify and explore. Firstly, as Conservative policy toward nonhuman animals has severely lacked respect and concern for welfare in recent years, this proposal must be met with scrunity and demand for further and more consistent developments in the future. Secondly, this increased measure to ensure the welfare of companion animals reflects a deep flaw in public thought regarding the nature of animal sentience; sentience is not reserved for those with whom we share our homes, but must be recognised, following scientific revelation, as innate to many non-companion animals also. 
The Daily Mail reveals valuable statistics that, in themselves, provide compelling reasoning in support of the proposal. When registering these numbers, it becomes abundantly clear that the punishments have hardly fitted the crimes. On the lower end of the spectrum, it reports that 'one in four animal cruelty cases is punished with only a fine", and the average penalty amount has dropped in recent years; "in 2005 it stood at $£ 479$ but fell to just $£ 296$ last year". In terms of convictions, progress has, thus far, been slow; "in 2005, just ten offenders were handed suspended jail terms, compared with 160 last year [2016]". Furthermore, "since 2005, 12 in every 13 people convicted for animal cruelty avoided jail", while "between 2013 and 2015 more than 3000 people in England and Wales were convicted of animal cruelty but just 7\% received jail terms". Statistics from the RSPCA, the country's leading animal welfare charity, show 143,004 complains of animal cruelty in 2014. Given the enormous number of cruelty cases, and the severe lack of punishment, many thousands of criminals are not being brought to justice, while those who are penalised get off too lightly.

The paucity of legal repercussions and laxity in their severity becomes even less tolerable when considering the heinous and abominable nature of the cruelest abuse. Earlier this year two men hammered a nail into the head of a deaf and blind dog and buried it alive in a "failed euthanasia attempt", for which they each received a four month jail sentence. Veterinary inspection of Scamp revealed there to have been "a minimum of six blows to the head", while the chairmen of the bench concluded it to be "a barbaric act [that] was premeditated and caused untold suffering". Dismayed at the limits of the current sentencing guidelines, local MP Anna Turley remarked that this case highlighted the "inadequacy of the law", predicting that "they will probably only be in prison for two months".

Other outageous cases with meager sentences include the case of Jennifer Lampe, who received a four-month suspended sentence after having "drunkenly decapitated her two snakes with scissors before swallowing their heads"; the case of Gary Samuel, who was given a 12-week suspended sentence when found keeping "dogs locked in cages in a filthy pitch-black dungeon", and the case of Paul Rogers, who received a 16-week jail sentence for "microwaving a rabbit to death because he was angry"; an act for which, as he proudly admitted, he felt "no remorse whatsoever".

Among further atrocious examples, the public outcry for change most recently manifested following the sentencing of Andrew and Daniel Frankish for the abuse to which they subjected their pet dog. The teenaged brothers filmed themselves repeatedly stamping on the Baby the bulldog and throwing her down stairs. As a result, "the dog became paralysed in the back legs and was eventually put down", yet they were only given a suspended sentence at Hartlepool Magistrates Courty; even if they had been jailed, the current sentencing powers would have allowed for their release after just three months.

Given the vile nature of these crimes, the move to increase the maximum punishment has been well received by many stakeholders that have long sought change. Chief Executive of the League Against Cruel Sports Phillipa King believes it to be "excellent news that the Government has listened to people who are dealing with this on the front line". She especially praised the possibility for a tougher stance on dog fighting; she criticises current law, calling it a "pitiful deterrent", but commending any possible proposal that leads to a 5 year sentence as "a massive step forward".

Head of Campaigns for the RSPCA David Bowles, speaking on behalf of the organisation, expressed how thrilled they are "that the Government has responded to calls from the RSPCA and members of the public to toughen up sentences for the worst animal abusers". Describing how RSPCA inspectors "regularly rescue animals from horrific circumstances of mistreatment, brutality and neglect", he remarks that it is only through RSPCA prosecutions that "many of the perpetrators are brought to justice". With sentences potentially going to reflect the seriousness of the crime, he further hopes that "this will act as a real deterrent against cruelty and neglect”. 
Indeed, an increase in sentencing powers to enable greater protection for companion animals would reflect a deeper desire to protect nonhuman animals, as well as reinforce the idea that animal welfare is, without doubt, a priority. As Claire Horton, chief executive of Battersea Dogs' and Cats' Home crucially drew the comparison, "six months in prison for the gravest act of animal cruelty, such as torturing an animal to death, is a fraction of the maximum sentence for fly tipping [five years] or theft [seven years]". While it is interesting to draw this comparison, it is, perhaps, only due to the fact that current sentencing guidelines "have not changed since the Protection of Animals Act 1911", and does not mean to suggest that currently fly tipping is considered to be more serious a crime than animal cruelty. However, by bringing our law up to date with public attitudes, as unequivocally reflected in the response to recent acts of cruelty, the Government is demonstrating an interest in making policies that reflect the will of the people, at least in regards to cruelty toward companion animals.

The change also comes about at an important time given the increasing recognition in recent years of the link between violence toward nonhuman animals and violence toward humans. While this is not the place to delve into this topic, it is beneficial to highlights that increased punishment for perpetrators of cruel or abusive behaviour toward nonhuman animals will, even if not intentionally, help to refocus attention on the perpetrator, irrespective of the nature of the victim. This will, in turn, reinforce the important point that it is the aggressor that must be blamed, rather than the victim or those around them. Therefore this legislative change should, if implemented, provide greater protection to any possible victims in abusive households, irrespective of species.

It is, undoubtedly, a positive step forward for the recognition and respect of nonhuman animal sentience, as national policy demonstrates greater adherence to the capabilities of companion animals to suffer and the trauma that they experience when being tortured and abused. However, in aknowledging this, it is equally impossible to ignore the deep flaw that this reveals in our attitude, as a nation, toward nonhuman animals in general. We, as a nation, are proud to treat our pets as a member of the family, to condemn whaling and big game hunting and dog meat festivals, but too frequently we shut our eyes to the cruelty to which we contribute on a daily basis. I am, of course, referring to the indirect cruelty to which we subject nonhuman animals on a non-stop basis; consuming their flesh and excrements, wearing their skin, and subjecting them to a life of servitude as biological machines. Sentience is not reserved only for the nonhuman animals in which we choose to see it; those close to us, the exotic, or the ones that appear to more greatly resemble ourselves. Scientific study into the awareness and sentience, both biological and emotional, of many species of nonhuman animal increasingly reveals their ability to feel pain and suffer both physically and psychologically. As Michael Gove proudly insists on us as being "a nation of animal lovers", it is only fair that we, as a nation, strive to ensure that our ethic and laws reflects this sentiment in which we take such pride.

In this sense, we must not let ourselves be appeased by this single proposition of legislative reform, but instead remain diligent in our scepticism toward and scrutiny of Conservative Party policy toward the treatment of nonhuman animals in general. Conservative policy has, in recent years, been inimical to nonhuman animal welfare development; there are three key examples of this that must not be overlooked.

Firstly, this can be seen in the failure of the Conservative Government to implement the Circus Animals Draft Bill and bring about the proposed, and promised, improvements in the conditions of wild animals kept in circuses. The draft Bill, initially suggested by the Labour Party in 2010 and developed under the following Coalition Government, attempted to implement a total ban on use of wild animals in travelling circuses, as well as conferring extensive powers of investigation and enforcement on authorities, following public outrage at the treatment of wild animals in such conditions. In the form of a written response, the Convervative Government published their intention to implement the Bill "as soon as the legislative programme [allowed]". However by failing to bring the draft Bill to fruition, 
wild animals in circuses continue to suffer under the licensing scheme, which has proved itself incapable of meeting necessary welfare standards.

The second clear example is the staunch Conservative desperation to repeal the foxhunting ban enshrined in the Hunting Act. Praised by the League Against Cruel Sports as "the most succesful piece of animal welfare legislation in history", and receiving the support of " $80 \%$ of the British public", the piece of legislation has been faced with multiple attacks from the Tory political agenda. Former Prime Minister David Cameron promised during his campaign that upon winning the election he would "hold a parliamentary vote on repealing the fox hunting ban", unsubstantiatedly claiming that "the Hunting Act [had] done nothing for animal welfare”. It was only when the Scottish National Party held that it would vote against this "shabby attempt to repeal a succesful piece of animal welfare legislation by the back door" that Cameron withdrew his promise. Current Prime Minister Teresa May also pledged to hold a free vote on repealing the ban before gaining a majority in the June 2017 General Election, however fortunately the attention of the Government appears too occupied to spare time for this whim.

The third example is an initiative led by former Environment Secretary Liz Truss that sought the repeal of nonhuman animal welfare codes in the form of a draft order to bring about industry-led deregulation. The initiative would start with the poultry industry and possibly develop to cattle, sheep, and pig farming also. This possible development sparked fear from animal charities that the move could "weaken animal welfare standards in farms and lead to fewer prosecutions for animal cruelty". The move was further criticised by the Labour party for "endangering Britain's proud tradition as a country that stands up for animal welfare", and by the then shadow Environment Secretary Kerry McCarthy, who rightly argued that "abandoning codes of practice for farm animal welfare is not in the best interests of the animals".

Most recently there has been warranted scepticism as to the effect of Britains exit form the European Union on national animal welfare standards, most specifically for farmed animals. Particular concern was refected in a report from the House of Lords, which warned that "the standards of UK producers could be put under pressure by demands from other countries to allow an influx of cheap and lower-standards food as part of trade deals". Further to this, the House of Lords subcommittee on EU Energy and Environment reasoned that "the government's wish for the UK to become a global leader in free trade is not necessarily compatible with its desire to maintain high animal welfare standards". As "UK farmers could be undermined by imports of cheap meat and milk produced to low welfare standards", Peter Stevenson, Chief Policy Advisor for Compassion in World Farming, fears that "British farmers are likely to opposed an improvements in animal welfare and may press for existing standards to be weakened".

While the decision to leave the European Union was voted by the country as a whole, the Tory leadership of the Brexit has so far, in terms of animal welfare, shown little positive sign of concern for welfare of farmed animals. Teresa May, addressing Parliament, issued the following statement: "We should be proud that in the UK we have some of the highest animal welfare standards in the world - indeed, one of the highest scores for animal protection in the world. Leaving the EU will not change that”. Gove also brushed off complaints for the absence of Article 13 of the Treaty of Lisbon - enshrining the requirement for ministers to account for animal welfare when drawing up new policies - in the EU Withdrawal Bill, stating it to be "an absolutely vital commitment that we have to ensure that all creation is maintained, enhanced, and protected". However, the truth in these words will not be known until progress is made with trade talks. Recent discussion between Secretary of State for International Trade Liam Fox and President Trump on prospective trade deals already highlighted a possible drop in standards as the UK would move from the EU's "high standard control over chicken and food to the chlorinated, full of hormones, US chicken”. This would essentially mean no longer importing produce from countries that meet the current EU welfare regulations to which we also adhere, and insead importing 
meat from countries that, according to certain EU sources, "rely on chlorine as a decontaminant to cover for laxer welfare and sanitary conditions”.

While the UK is currently busy negotiating its separation terms from the European Union, the EU Dog and Cat Alliance have been calling for the better regulation of the online sale of pets. The Alliance has "launched an EU Pet Advertising Advisory Group (EUPAAG), which aims to bring together pet selling websites, animal welfare organisations and relevant government department representatives to agree on a set of voluntary minimum standards and guidelines for advertising pets online”. Indeed, any increased legislation to improve the welfare of nonhuman animals is beneficial. While increased sentencing powers are effective for bringing abusers to justice post-crime, as well as acting as a potential deterrent, an improvement in the regulation of online sales would further prevent abuse by attacking the source and making it harder for abusers to get hold of animals in the first place. With over " 400,000 adverts for dogs, 100,000 for cats and thousands more for exotic animals in the 21 Member States [looked at]... in some countries, where no regulations exist, animals are being sold with no thoughts to welfare at all”.

It can therefore be said, without reserve, that this most recent Conservative proposal for improving animal welfare must be met not with pride and relief, but with a thirst for further improvement and an increasingly all-encompassing respect for the sentience of nonhuman animals. In a time of nationwide ideological division, this populist policy may be nothing more than the Conservative hand grasping for public unity through its shared love for animals. This idea is both settling and unsettling; political future lies in darkness, but concern for nonhuman animals, a flicker of light. However if the recent shifting of political plates has cracked open space for welfare concerns, it is this opportunity, and this opportunity alone, that we should exploit.

\section{BIBLIOGRAPHY}

\section{Websites:}

1. “Animal Cruelty Sentences to Rise to Five Years in Prison”, (30 September 2017, BBC), accessed 27 October 2017 accessed 27 October 2017

2. "Animal Cruelty: New Law will Increase Penalty for Abuse to Five Years in Prison”, (30 September 2017, The Independent), accessed 27 October 2017

3. “Could Brexit Lower Animal Welfare Standards?” (25 July 2017, Compassion in World Farming) accessed 27 October 2017

4. "Men Jailed for Burying Dog Alive after Driving Nail into its Head", (1 March 2017, The Guardian) accessed 27 October 2017

5. “ “Online Sale of Pets: What's The Cost?” (29 September 2017, EU Dog and Cat Alliance), accessed 27 October 2017

6. Becket, Adam. 25.7.17, "Brexit Poses a Threat to Animal Welfare in the UK, a new report warns” (25 July 2017, Business Insider), accessed 27 October 2017

7. Bell, Bethan. “Are we Tough Enough on Animal Cruelty?” (24 February 2017, BBC), accessed 27 October 2017

8. Boffey, Daniel \& Elgot, Jessica. “Brussels Attacks Liam Fox’s ‘Ignorant' Remarks on Chlorinated Chicken” (25 July 2017, The Guardian), accessed 27 October 2017

9. Doyle, Jack. "Five-year Jail Terms for Animal Cruelty Crimes are Planned by Gove as Offenders Continue to get off Lightly”, (29 September 2017, The Daily Mail), accessed 27 October 2017 
10. Harvey, Fiona. "Post-Brexit Trade Deals 'Threaten UK's Animal Welfare Standards”, (25 July 2017, The Guardian) accessed 27 October 2017

11. Mason, Rowena. "Government shelves foxhunting vote after SNP opposition”, (The Guardian, 14 July 2015), accessed 27th October 2017

12. Merrick, Rob. "Michael Gove Accused of Backtracking on Pledges to Protect Animal Welfare because of Brexit”, (28 October 2017, The Independent), accessed 28 October 2017

13. Osbourne, Samuel. "Teresa May announces she wants to bring back fox hunting”, (The Independent, 9 May 2017), accessed 27th October 2017

14. Stone, Jon. "David Cameron says he wants to repeal the fox hunting bill", (The Independent, 6 March 2015), accessed 27th Ocober 2017

15. Winter, Stuart. "The Cruel, the Bad and the Sickening... Britain's Pet Crime Shame”, (23 March 2016, The Express)

\section{Books}

1. Arkow, Phil. The Evolution of Animal Welfare as a Human Welfare Concern, in Ascione, Frank R., and Arkow, Phil. (1999). Child Abuse, Domestic Violence, and Animal Abuse: Linking the Circles of Compassion for Prevention and Intervention. West Lafayette, Indiana: Purdue University Press. p19

\section{Journal Articles}

1. Proctor, Helen. “Animal Sentience: Where are We and Where are We Heading?” 2012, accessed 27 October 2017

\section{Legislation}

1. $\quad$ The Hunting Act 2004, contents accessed 27 October 2017

2. $\quad$ The Lisbon Treaty, Article 13

\section{Bills}

1. HM Government, Wild Animals In Circuses (Draft), April 2013, Briefing Paper, accessed 27 October 2017

2. $\quad$ The European Union (Withdrawal) Bill

\section{Declarations}

1. Low, Phillip; Panksepp, Jaak; Reiss, Diana; Edelman, David; Van Swinderen, David, and Koch, Christof. "The Cambridge Declaration on Consciousness". (7 July 2012, Cambridge), accessed 27 October 2017 